\title{
Physicochemical properties of skim milk powder dispersions prepared with calcium-chelating sodium tripolyphosphate, trisodium citrate, and sodium hexametaphosphate
}

Inseob Choi (D) and Qixin Zhong* (D)

Department of Food Science, The University of Tennessee, Knoxville 37996

\begin{abstract}
Due to health benefits of proteins, the demand for protein beverages has grown rapidly. Translucent protein drinks with neutral $\mathrm{pH}$ may have advantages over acidic beverages that may cause dental erosion, and skim milk powder (SMP) is an affordable protein ingredient. Dissociating casein micelles by calcium chelators is a well-known method to reduce SMP dispersion turbidity, but much is to be studied for physicochemical properties as affected by chelator type and concentration. The objective of the present study was to characterize physicochemical properties of dispersions with 5\% (wt/vol) SMP after addition of 0 to $30 \mathrm{mM}$ sodium tripolyphosphate, trisodium citrate, or sodium hexametaphosphate. The turbidity was decreased with increasing chelator concentration, with the lowest turbidity observed in the SMP dispersions with sodium hexametaphosphate. The smallest hydrodynamic diameter was observed at an intermediate chelator concentration, resulting from the balance of casein micelle dissociation and aggregation of dissociated caseins induced at an elevated ionic strength. Heating at $90^{\circ} \mathrm{C}$ for 5 min increased turbidity but lowered hydrodynamic diameter of SMP dispersions, with some exceptions. The morphology of SMP dispersions differed for each chelator and was also affected by chelator concentration and heating. Trisodium citrate was the most effective to demineralize colloidal calcium phosphate in casein micelles, but the amount of dissolved calcium was not directly correlated with the decreased turbidity, indicating different chelating mechanisms by each chelator. Analysis of serum calcium and phosphorus concentrations also suggested that the type and concentration of soluble and insoluble calcium phosphates and their partitioning in the serum and casein micelles were dynamically changed by the studied parameters
\end{abstract}

Received April 3, 2020.

Accepted June 10, 2020

*Corresponding author: qzhong@utk.edu to affect dispersion turbidity and structures of casein micelles. Findings from the present study may be used to formulate translucent beverages incorporating SMP and other casein micelle ingredients.

Key words: skim milk powder dispersion, casein micelle, calcium chelator, colloidal calcium phosphate

\section{INTRODUCTION}

The increased demand for proteins is expected with the projection that world population will rise to approximately 10 billion by 2050 (United Nations, 2015). In addition, the increased awareness that proteins contribute to healthier aging drives the increase in protein consumption, contributing to the steady growth of functional foods with proteins (Henchion et al., 2017). Incorporation of proteins, mainly whey protein isolate, into beverages has been attempted due to the functionalities of proteins, such as aiding muscle protein synthesis and increasing satiety (LaClair and Etzel, 2010; MacKenzie-Shalders et al., 2015). However, heat treatment used to pasteurize and sterilize beverages can cause aggregation and precipitation of whey proteins, thus lowering acceptance by consumers (Rittmanic, 2006). Even though beverages with whey protein isolate can be clear at acidic $\mathrm{pH}$ of around 3.0, consumption of acidic beverages can cause dental erosion even in young people (Seow and Thong, 2005; LaClair and Etzel, 2010), which calls for clear beverages with neutral $\mathrm{pH}$.

Skim milk powder (SMP) is well dispersed in deionized water at neutral pH. Like milk, SMP provides casein and whey proteins at a ratio of approximately $4: 1$, with functionalities mostly determined by casein micelles and their structure (Dalgleish and Corredig, 2012). Calcium and phosphorus are the most important minerals for the structure of casein micelles. Calcium and phosphorus in the serum phase of SMP dispersions are in equilibrium with colloidal calcium phosphate (CCP) in casein micelles (Walstra, 1999). Colloidal calcium phosphate in casein micelles functions as "cement" to link phosphorylated residues to form the net- 
work structure of casein micelles (Horne, 1998, 2006). Cationic calcium of CCP also neutralizes phosphoserine residues of caseins (Schmidt, 1982), and the weakened electrostatic repulsion allows hydrophobic patches of casein molecules to interact with each other, which is also important to casein micelle structure (Horne, 1998). With the average dimension of casein micelles being around $200 \mathrm{~nm}$, SMP dispersions are turbid (Glantz et al., 2010), and the knowledge of the importance of $\mathrm{CCP}$ to casein micelle structure can be used to guide the dissociation of casein micelles to reduce dispersion turbidity. Such studies have been focused on disrupting CCP linkages by high hydrostatic pressure (Huppertz and De Kruif, 2007; Orlien et al., 2010; Bravo et al., 2013) or driving the calcium-phosphate balance from $\mathrm{CCP}$ in casein micelles to the continuous serum phase by addition of calcium-chelating agents (Panouillé et al., 2005; Kaliappan and Lucey, 2011; Lazzaro et al., 2017).

Chelators refer to materials that have high affinities to form complexes with cations and, therefore, can displace cations from original binding sites (Gaucheron, 2005). Calcium chelators can be added to milk or other dairy protein dispersions to improve rehydration properties of dairy powder or emulsifying capacity by altering physical interactions surrounding casein micelles (de Kort et al., 2011; Lazzaro et al., 2017; McCarthy et al., 2017). Various calcium chelators can dissociate casein micelles, including EDTA, citrate, and phosphate (Pitkowski et al., 2008; de Kort et al., 2011; Kaliappan and Lucey, 2011). Casein micelles are dissociated into small clusters, and specific caseins are released by mechanisms of chelators that govern protein-mineral equilibria, resulting in the reduced amount of diffusible calcium and depletion of CCP (de Kort et al., 2011). Therefore, the reduced turbidity of dispersions with casein micelles after addition of calcium-chelating agents has been reported frequently (Mizuno and Lucey, 2005; Pitkowski et al., 2008; Culler et al., 2017). The extent of turbidity reduction of casein micelle dispersions depends on the type and concentration of chelators with the decreasing chelating ability of polyphosphate $>$ citrate $>$ orthophosphate (Van Wazer and Callis, 1958). For example, milk after adding $1 \mathrm{~m} M$ sodium hexametaphosphate (SHMP) and $100 \mathrm{~m} M$ sodium tartrate at $\mathrm{pH} 7.8$ had comparable turbidity after 30 min of equilibrium (Culler et al., 2017). The type of calcium chelators added also affects heat stability of casein micelle dispersions; better stability was reported for dispersions with added disodium uridine monophosphate than for those with added trisodium citrate (TSC) or SHMP after sterilization at $126^{\circ} \mathrm{C}$, although the former is a weaker calcium chelator (de Kort et al., 2012). However, calcium and phosphorus compositions of SMP dispersions as affected by different types of calcium chelators and heating and the correlation with casein micelle structures are still to be studied.

The overall objective of the present study was to characterize physicochemical properties of SMP dispersions at $\mathrm{pH} 6.8$ after addition of calcium chelators and heating. Sodium tripolyphosphate (STPP), TSC, and SHMP were chosen due to the higher calcium binding affinity of polyphosphate and citrate than of orthophosphate (de Kort et al., 2009). Additionally, sodium sources were used to exclude possible effect of cationic counter ions in calcium chelators. Physicochemical properties of SMP dispersions were characterized for turbidity, hydrodynamic diameter $\left(\boldsymbol{D}_{\mathrm{h}}\right)$, ionic composition using inductively coupled argon plasma-optical emission spectrometry (ICP-OES), zeta-potential, and morphology using transmission electron microscopy (TEM).

\section{MATERIALS AND METHODS}

\section{Materials}

Carnation SMP was a product of Nestlé USA (Solon, $\mathrm{OH})$. The protein content of SMP was determined to be $35.4 \%$ based on the Kjeldahl method (AOAC International, 2005). The STPP (CAS no. 7758-29-4) was obtained from Acros Organics (Pittsburgh, PA), and TSC (CAS no. 68-04-2) and SHMP (CAS no. 1012456-8) were obtained from Alfa Aesar (Ward Hill, MA). Hydrochloric acid was purchased from Fisher Scientific (Fair Lawn, NJ).

\section{Sample Preparation}

The SMP dispersions were prepared by hydrating $\mathrm{SMP}$ at $5 \%$ (wt/vol) in $10 \mathrm{~mL}$ of deionized water in 20-mL scintillation vials. Deionized water was dissolved with each calcium chelator at $0,1,2,3,5,7,10,15$, or $30 \mathrm{~m} M$, with $0 \mathrm{~m} M$ being a control. Samples were incubated overnight at room temperature $\left(\mathbf{R T} ; \sim 21^{\circ} \mathrm{C}\right)$ and then adjusted to $\mathrm{pH} 6.80 \pm 0.02$ using $1.0 \mathrm{M} \mathrm{HCl}$ or $\mathrm{NaOH}$ solution. After $\mathrm{pH}$ adjustment, samples were also heated for $5 \mathrm{~min}$ in a water bath pre-equilibrated to $90^{\circ} \mathrm{C}$. Samples before and after heating were incubated at RT for about $12 \mathrm{~h}$ before measuring the following properties within $18 \mathrm{~h}$.

\section{Turbidity and $D_{h}$}

The turbidity of SMP dispersions was determined at RT using a 2020 we/wi turbidimeter (LaMotte, Chestertown, MD) equipped with a tungsten lamp and a photodiode detector. The measurement was recorded 
for nephelometric turbidity units (NTU). Dynamic light scattering was used to measure the particle size (model Zetasizer nano-ZS, Malvern Instruments, Malvern, UK). The viscosity used in dynamic light scattering was measured with a tuning-fork vibrational viscometer (SV-10, A\&D Co., Tokyo, Japan). The zaverage $D_{\mathrm{h}}$ from the cumulants analysis was reported. Measurements were done with a backscatter angle of $173^{\circ}$ and an equilibrium temperature of $25^{\circ} \mathrm{C}$.

\section{Concentrations of Calcium and Phosphorus in the Serum Phase}

To determine calcium and phosphorus concentrations in the serum phase of SMP dispersions, SMP dispersions were contained in the Amicon ultra-15 centrifugal filter unit equipped with an ultracel-10 membrane with a molecular weight cut-off of $10 \mathrm{kDa}$ (Merck Millipore Ltd., Cork, Ireland) and centrifugated for $3 \mathrm{~h}$ at 4,500 $\times g$ at $21^{\circ} \mathrm{C}$ (model RC-5B plus centrifuge, Sorvall, Newtown, CT). The permeate contained free ions and ion complexes smaller than the membrane pore, but not those bound with proteins. The permeate after dilution for 100 times with deionized water was analyzed using a Spectro Ciros ICP-OES instrument (Spectro Ciros, Mahwah, NJ). The ICP-OES standards (VHG Labs, Manchester, NH) were used in calibration, and the limit of detection was $0.01 \mathrm{mg} / \mathrm{L}$ for both calcium and phosphorus.

\section{Zeta-Potential}

The SMP dispersions were adjusted to $\mathrm{pH} 6.80 \pm$ 0.02 using $1.0 \mathrm{M} \mathrm{HCl}$ or $\mathrm{NaOH}$. The zeta-potential of SMP dispersions was determined at $25^{\circ} \mathrm{C}$ with $120 \mathrm{~s}$ of equilibration time using the above Malvern instrument. The instrument measures electrophoretic mobility $\left(U_{E}\right.$; calculated as $\mu \mathrm{m} \times \mathrm{cm} / \mathrm{V} \times \mathrm{s}$ ) on the basis of laser doppler electrophoresis to derive zeta-potential from the Henry equation:

$$
U_{E}=\left(\frac{2 \varepsilon \zeta}{3 \eta}\right) f(k a)
$$

where $\varepsilon$ is the dielectric constant of solvent $(\mathrm{F} / \mathrm{m}), \zeta$ is zeta-potential $(\mathrm{mV}), \eta$ is the viscosity of solution $(\mathrm{Pa} \cdot \mathrm{s})$, and $f(k a)$ is Henry's function (de Kort et al., 2012).

\section{TEM}

The morphology of SMP dispersions was studied using TEM. A freshly glow discharged 400 mesh cop- per grid with a thin carbon film was placed on $50 \mu \mathrm{L}$ of an SMP dispersion droplet deposited on a piece of Parafilm (Bemis Co., Neenah, WI). After removing excess sample with a piece of Kimwipes (Kimberly-Clark, Irving, TX), the grid was washed briefly by placing on a drop of water. The washed grid was stained by placing on a drop of $1 \%$ uranyl acetate for $1 \mathrm{~min}$. After removing excess stain using a piece of Kimwipes, the sample was dried at RT before imaging on a Zeiss Libra 200MC (Carl Zeiss Inc., Fort Lauderdale, FL) operating at $200 \mathrm{kV}$.

\section{Statistical Analysis}

Statistical analyses were conducted using SAS Enterprise Guide 7.1 (SAS Institute Inc., Cary, NC) with 1-way ANOVA. Fisher's least significance difference test was used to calculate mean \pm standard deviation from the sample in duplicate on each test, and differences of calculated mean values were considered significant at $P<0.05$.

\section{RESULTS AND DISCUSSION}

\section{Turbidity and $D_{h}$ of SMP Dispersions as Affected by Chelators}

As expected, increasing the concentration of calcium chelators resulted in visually more transparent SMP dispersions (Figure 1). The decrease in the turbidity of SMP dispersions with increasing calcium chelator concentration was observed for all 3 chelators (Figure 2 ). With $1 \mathrm{~m} M$ chelator, the turbidity of SMP dispersions was 1,125, 1,429, and 571 NTU for STPP, TSC, and SHMP treatments, respectively, reflecting their differences in calcium-chelating ability. The binding affinity of chelators to calcium relies on temperature, $\mathrm{pH}$, and valency of chelators (Lucey et al., 2011). With the temperature and $\mathrm{pH}$ being similar in the present study, the SMP dispersion turbidity after addition of 1 $\mathrm{m} M$ chelator is correlated with the number of negative charges of STPP $(\mathrm{n}=5)$, TSC $(\mathrm{n}=3)$, and SHMP (n $=6 ;$ McCarthy et al., 2017). However, the difference in the turbidity of SMP dispersions was minimized at the chelator concentration of $30 \mathrm{~m} M$, showing 238,251 , and 232 NTU for STPP, TSC, and SHMP treatments $(P$ $<0.05$ ), respectively, suggesting that $30 \mathrm{~m} M$ chelators may be close to a plateau concentration at which most available casein micelles are dissociated regardless of the chelator charge. A previous study (McCarthy et al., 2017) reported that the turbidity of dispersions with $0.5 \%$ (wt/vol) milk protein concentrate was not significantly different for treatments with $10 \mathrm{~m} M$ TSC (68.18 NTU) and $5 \mathrm{mM}$ SHMP (68 NTU), which had the same 
level of equivalent chelating capacity $(\mathrm{mEq} / \mathrm{L})$. In the present study, a significant difference in turbidity was observed for the SMP dispersions with $10 \mathrm{mM}$ TSC (277 NTU) and $5 \mathrm{~m} M$ SHMP (249.5 NTU). The difference between these 2 studies can be explained by the higher micellar casein concentration in the present study $(\sim 1.4 \% \mathrm{wt} / \mathrm{vol})$ requiring a higher concentration of chelators to reduce the turbidity of SMP dispersions.

When $D_{\mathrm{h}}$ was examined (Figure 3 ), the decrease in $D_{\mathrm{h}}$ with an increase in chelator concentration was observed only at a lower chelator concentration range (0-3 $\mathrm{m} M$ for STPP, $0-7 \mathrm{~m} M$ for TSC, and 0-2 $\mathrm{m} M$ for SHMP). For each chelator, the smallest $D_{\mathrm{h}}$ was observed at an intermediate chelator concentration, which is different from the monotonic decrease in SMP dispersion turbidity with increasing calcium chelator concentration (Figure 2). The turbidity of a dispersion is a function of particle dimension as well as concentration and compactness (i.e., the ability to reflect light) of particles (Jonassen et al., 2012). At an increased ionic strength, the electrostatic repulsion is weakened due to charge screening effect (Saricay et al., 2019) to cause aggregation of dissociated caseins and therefore the increased $D_{\mathrm{h}}$ (Figure 3 ), whereas casein aggregation lowers particle concentration to cause a continued decrease in turbidity (Figure 2).

\section{Turbidity and $D_{h}$ of SMP Dispersions with Chelators as Affected by Heating}

Heating influenced both $D_{\mathrm{h}}$ and turbidity of SMP dispersions with calcium chelators (Figures 1-3). Some dispersions experienced a significant change in visual appearance after heating, such as treatments with 2, 15, and $30 \mathrm{~m} M$ STPP (Figure 1). An increase in turbidity was observed after heating SMP dispersions at all studied STPP concentrations (Figures 2a). Particularly, the addition of STPP at 15 or $30 \mathrm{~m} M$ increased turbidity more than 10-fold after heating, indicating the formation of larger structures. The precipitation observed for these 2 treatments after heating suggested the possible formation of insoluble calcium-STPP complexes that could also involve proteins. Similarly, heating increased the turbidity of most dispersions with TSC except at 3 and $30 \mathrm{~m} M$ (Figure 2b). As for the SHMP treatments, the turbidity after heating increased at 1 and $2 \mathrm{mM}$ SHMP but decreased at 10 to $30 \mathrm{~m} M$ SHMP $(P<$ $0.05)$, whereas the heating effect was insignificant $(P>$ 0.05 ) at 3 to $7 \mathrm{mM}$ SHMP (Figure 2c).

The effect of heating on $D_{\mathrm{h}}$ (Figure 3 ) showed a different trend than turbidity (Figure 2). Most treatments showed a decrease in $D_{\mathrm{h}}$ (Figure 3 ) after heating, except at 15 and $30 \mathrm{mM}$ STPP and 5 to $15 \mathrm{mM}$ TSC. This is further discussed below for effects of heating on changes in calcium and phosphorus concentrations.

After heating, $\mathrm{pH}$ of the dispersion without chelators decreased $(P<0.05)$, but the trend for dispersions with chelators depended on the type of chelators (Figure 4). No significant changes in $\mathrm{pH}$ were observed for TSC treatments $(P>0.05)$. A significant decrease in $\mathrm{pH}$ after heating was observed for dispersions with 1 to 5 $\mathrm{m} M \mathrm{STPP}$ or 1 to $15 \mathrm{~m} M \mathrm{SHMP}(P<0.05)$, with the lowest $\mathrm{pH}$ observed at an intermediate chelator concentration, whereas a significant increase $(P<0.05)$ in $\mathrm{pH}$ was observed at $30 \mathrm{~m} M$ STPP (Figure 4). The overall $\mathrm{pH}$ change trend after heating SMP dispersions with different concentrations of chelators generally agreed with changes of $D_{\mathrm{h}}$ for STPP and SHMP treatments but not those of TSC (Figure 3). There was also no correlation between $\mathrm{pH}$ change (Figure 4) and turbidity change (Figure 2) after heating.

The $\mathrm{pH}$ can affect turbidity and $D_{\mathrm{h}}$ of SMP dispersions in 2 different ways. In general, the calcium binding affinity of chelators is higher at a higher $\mathrm{pH}$ (Lucey and Fox, 1993; de Kort et al., 2009; McIntyre et al., 2016), and a slight increase in turbidity can be expected at a decreased $\mathrm{pH}$ (after heating) due to decomplexation of calcium and chelators. In preliminary experiments, sedimentation occurred rapidly after heating the SMP dispersions with 15 and $30 \mathrm{~m} M$ STPP at $\mathrm{pH} 6.80$, whereas no precipitation was observed after heating SMP dispersion at $\mathrm{pH} 8.50$ even with 50 to $200 \mathrm{mM}$ STPP. It then appears that the cause of $\mathrm{pH}$ changes after heating is the ionic composition in the serum phase, discussed below, which is further complicated by dynamic binding with proteins (de Kort et al., 2009).

\section{Calcium and Phosphorus Concentrations in Serum Phase of Dispersions as Affected by Chelators and Heating}

Calcium and phosphorus concentrations in the serum phase of SMP dispersions were studied using ICP-OES, presented in Tables 1 and 2, respectively. In milk, calcium can be present as either ions or soluble nonionic species (e.g., chelates and complexes) in the serum or as colloidal particles in casein micelles (DeMan et al., 1999). At low chelator concentrations in SMP dispersions, changes in both calcium and phosphorus concentrations in the serum were insignificant $(P>0.05)$ for all 3 calcium chelators, whereas significant $(P<0.05)$ increases in both calcium and phosphorus concentrations were observed at higher concentrations of chelators except for phosphorus concentration with TSC. However, due to the presence of phosphate in STPP and SHMP, the contribution of CCP to the increase of 

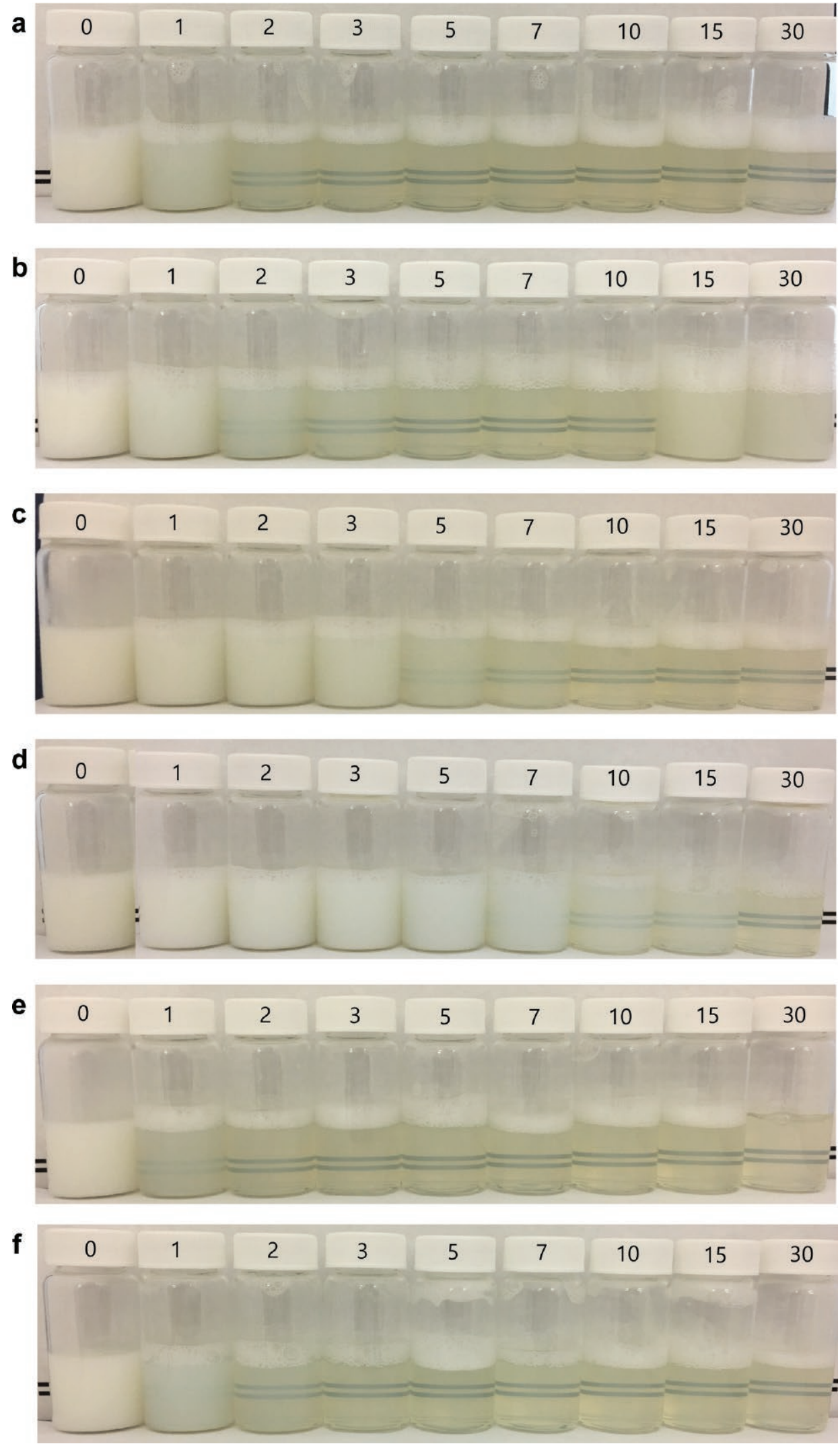

Figure 1. The appearance of $5 \%$ (wt/vol) pH 6.80 skim milk powder dispersions with 0 to $30 \mathrm{~m} M$ sodium tripolyphosphate (a, b), trisodium citrate (c, d), or sodium hexametaphosphate (e, f) before (a, c, e) and after (b, d, f) heating at $90^{\circ} \mathrm{C}$ for 5 min. 
a
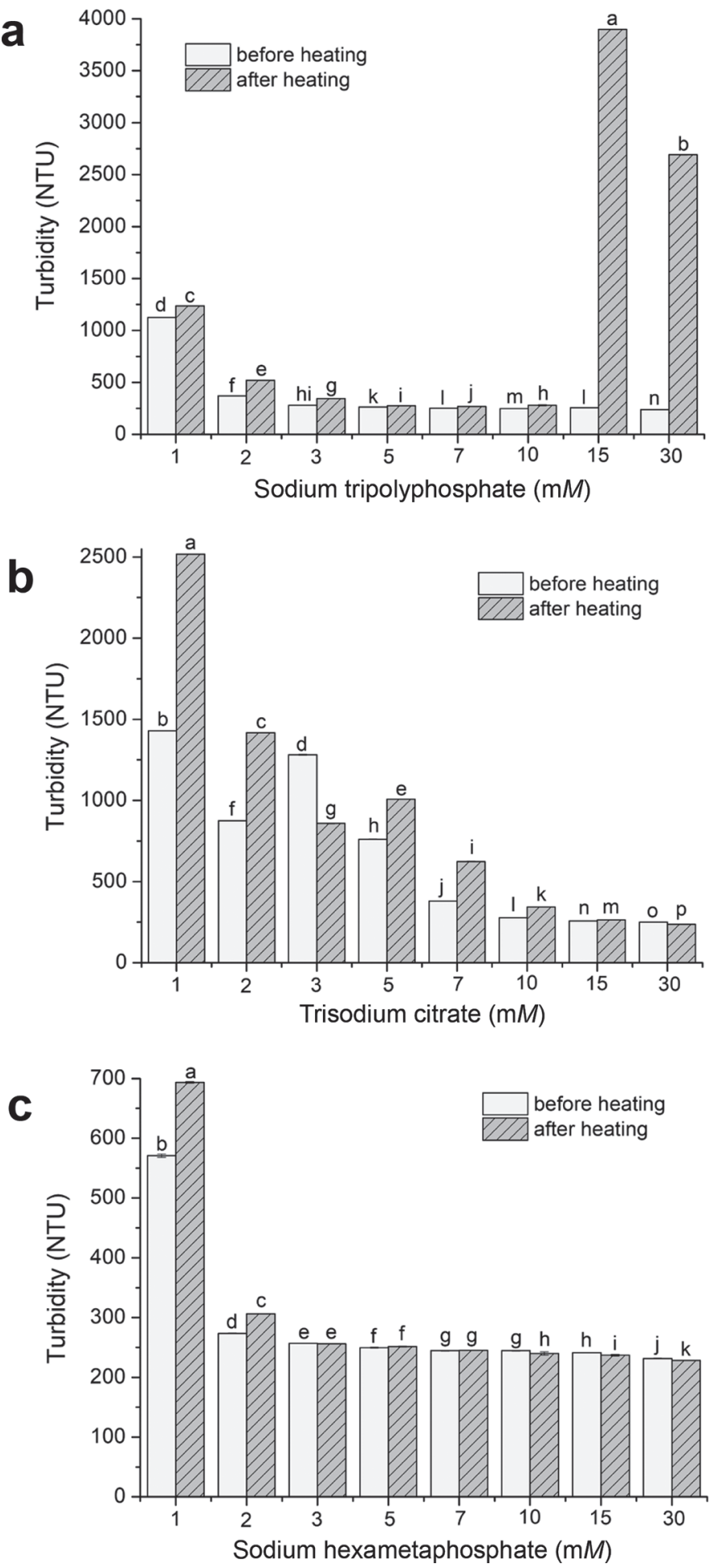

Figure 2. The turbidity of $5 \%$ (wt/vol) pH 6.80 skim milk powder dispersions with 0 to $30 \mathrm{~m} M$ sodium tripolyphosphate (a), trisodium citrate (b), or sodium hexametaphosphate (c) before and after heating at $90^{\circ} \mathrm{C}$ for $5 \mathrm{~min}$. Different letters $(\mathrm{a}-\mathrm{p})$ above bars indicate significant difference $(P<0.05)$. Error bars are SD $(\mathrm{n}=2)$. NTU $=$ nephelometric turbidity units.

Journal of Dairy Science Vol. 103 No. 11, 2020 a

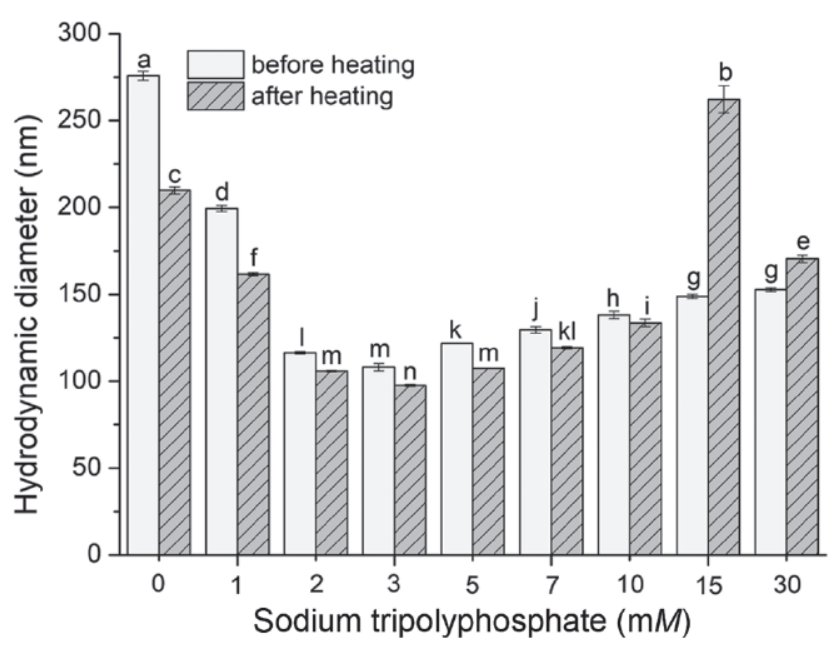

b
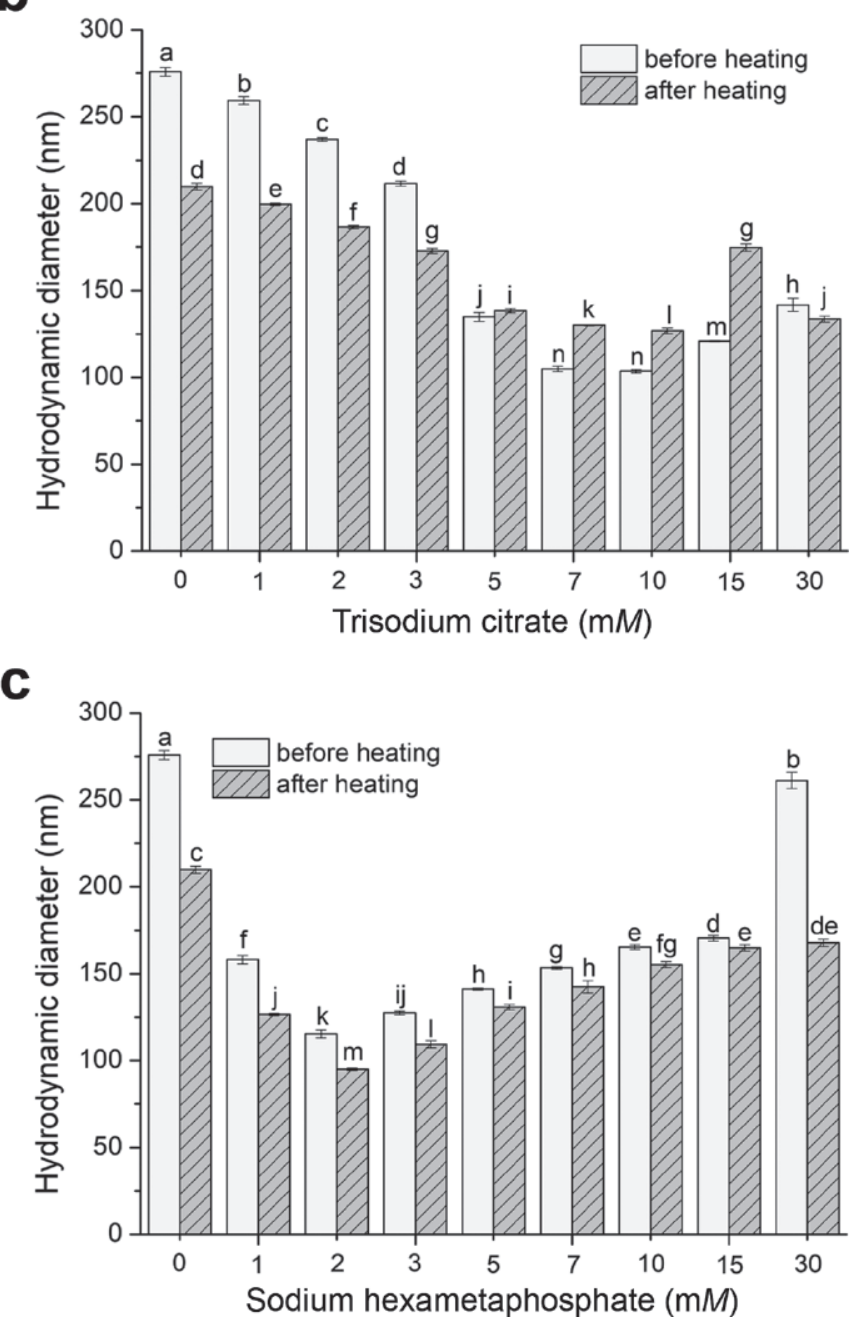

Figure 3. The z-average hydrodynamic diameter of $5 \%$ (wt/vol) pH 6.80 skim milk powder dispersions with 0 to $30 \mathrm{mM}$ sodium tripolyphosphate (a), trisodium citrate (b), or sodium hexametaphosphate (c) before and after heating at $90^{\circ} \mathrm{C}$ for $5 \mathrm{~min}$. Different letters $(\mathrm{a}-\mathrm{n})$ above bars indicate significant difference $(P<0.05)$. Error bars are $\mathrm{SD}(\mathrm{n}=2)$. 
a

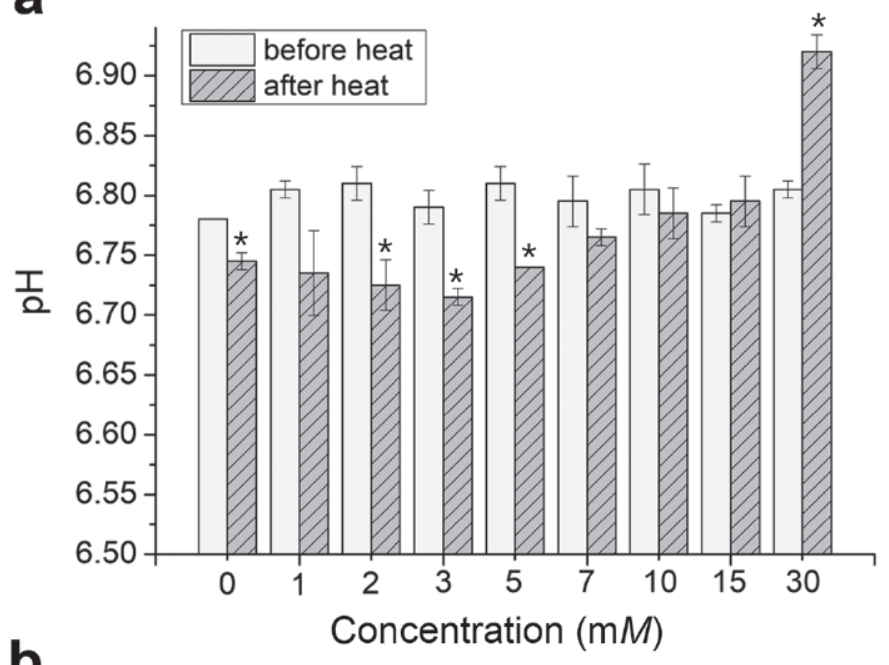

b

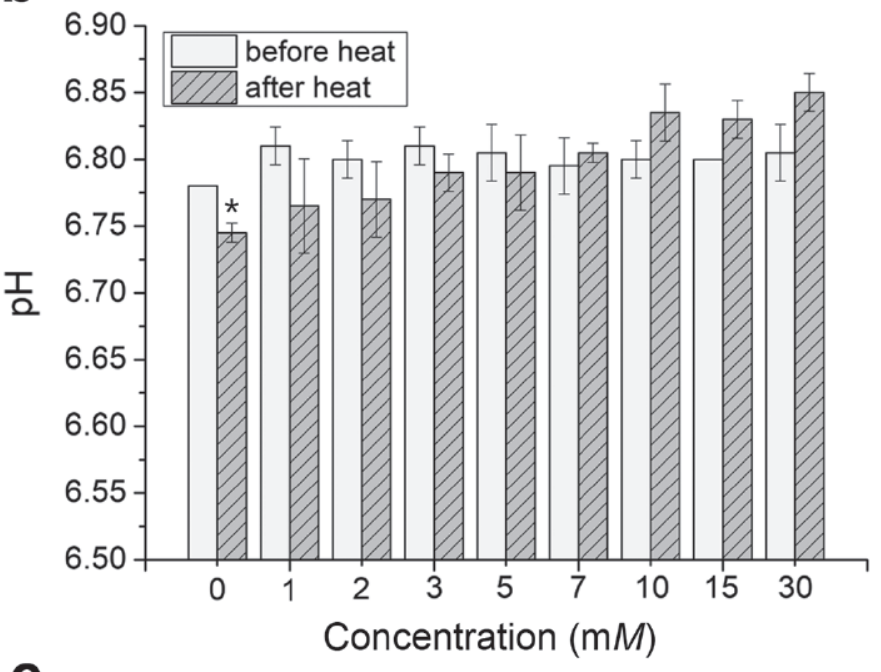

C

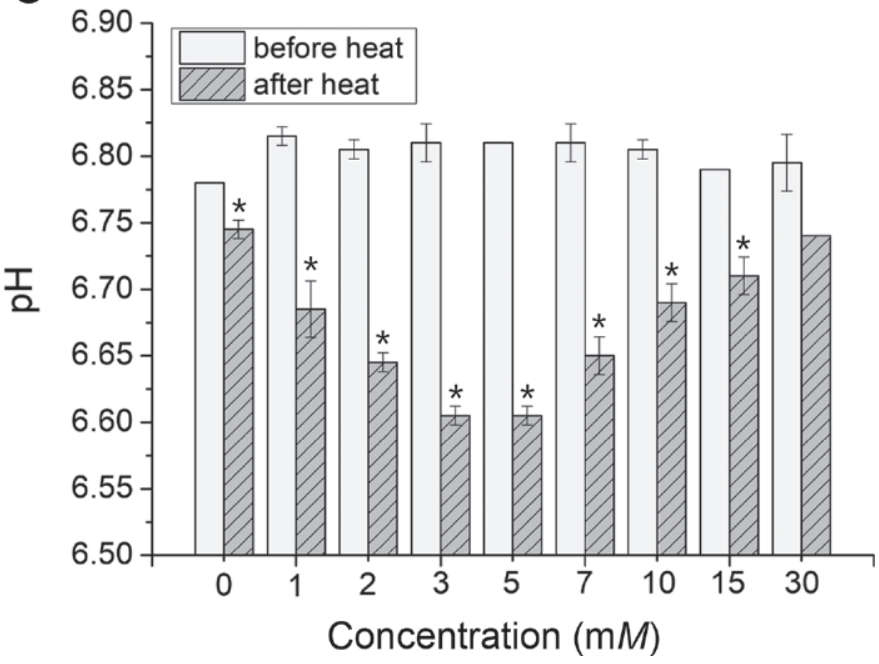

Figure 4. The $\mathrm{pH}$ changes of $5 \%$ (wt/vol) $\mathrm{pH} 6.80$ skim milk powder dispersions with 0 to $30 \mathrm{~m} M$ sodium tripolyphosphate (a), trisodium citrate (b), or sodium hexametaphosphate (c) before and after heating at $90^{\circ} \mathrm{C}$ for $5 \mathrm{~min}$. Asterisks above bars indicate significant difference $(P<0.05)$ before and after heating. Error bars are SD $(\mathrm{n}=2)$. phosphorus concentration in the serum phase of SMP dispersion was not clear. Therefore, the phosphorus concentration contributed by STPP and SHMP was calculated (Table 2). For STPP treatments, the serum phosphorus concentration was higher than the amount of STPP added, whereas the opposite was observed for SHMP treatments, indicating that phosphates from SHMP bound with proteins or formed insoluble inorganic complexes larger than the membrane pores used to separate the serum for mineral analysis.

Calcium phosphates can exist as various forms comprising different amounts of calcium and phosphates (Kezia et al., 2017). The mass ratio of calcium and phosphorus $(\mathrm{Ca} / \mathrm{P})$ was 0.62 in the SMP dispersion serum without chelators. The $\mathrm{Ca} / \mathrm{P}$ ratio gradually decreased to 0.1683 and 0.0880 when STPP and SHMP concentration increased to $30 \mathrm{~m} M$, respectively. On the other hand, the $\mathrm{Ca} / \mathrm{P}$ ratio gradually increased to 1.27 with an increase in TSC added into SMP dispersions. The formation of various calcium phosphate compounds is affected by $\mathrm{pH}$ and temperature as well as concentrations of calcium and phosphates and ionic strength (Dorozhkin, 2014). Therefore, it is probable that the increased concentration of phosphates and the increased ionic strength after adding STPP or SHMP exerted the counteracting effects on dynamic equilibria among various calcium phosphate compounds. Calcium phosphates can be soluble in various forms in aqueous dispersions with different $\mathrm{Ca} / \mathrm{P}$ ratios - for example, 0.5 for monocalcium phosphate monohydrate, 1.0 for dicalcium phosphate dihydrate, 1.2 to 2.2 for amorphous calcium phosphates, and 1.5 to 1.7 for calcium-deficient hydroxyapatite (Kezia et al., 2017). The increased Ca/P ratio with increasing TSC addition level suggests the increased tendency of calcium and phosphorus from casein micelles to form amorphous calcium phosphates or calcium-deficient hydroxyapatite in the serum of SMP dispersions (Kezia et al., 2017). The opposite trend may be the case for STPP and SHMP treatments.

Calcium chelators bind to calcium ions with different affinity forming soluble or insoluble complexes (de Kort et al., 2009). The reason why SMP dispersions had different turbidity at the same concentration of different calcium chelators (Figure 2) is probably because each chelator has a different calcium-binding capacity and causes different dynamic ionic equilibria in the serum and different casein structures via several factors. First, soluble calcium and casein-bound calcium are complexed by chelators, with the extent depending on the chelator type and concentration. Then, the bonding between CCP and casein in micelles is disrupted, causing disintegration of casein micelles and the increased calcium and phosphorus concentrations in the serum phase with increased chelator concentration (Tables 1 
Table 1. Calcium concentration $(\mathrm{mg} / \mathrm{L})$ in the serum phase of $5 \%$ (wt/vol) $\mathrm{pH} 6.80$ skim milk powder dispersions after addition of 0 to $30 \mathrm{~m} M$ sodium tripolyphosphate (STPP), trisodium citrate (TSC), or sodium hexametaphosphate (SHMP) before or after heating at $90^{\circ} \mathrm{C}$ for 5 min ${ }^{1}$

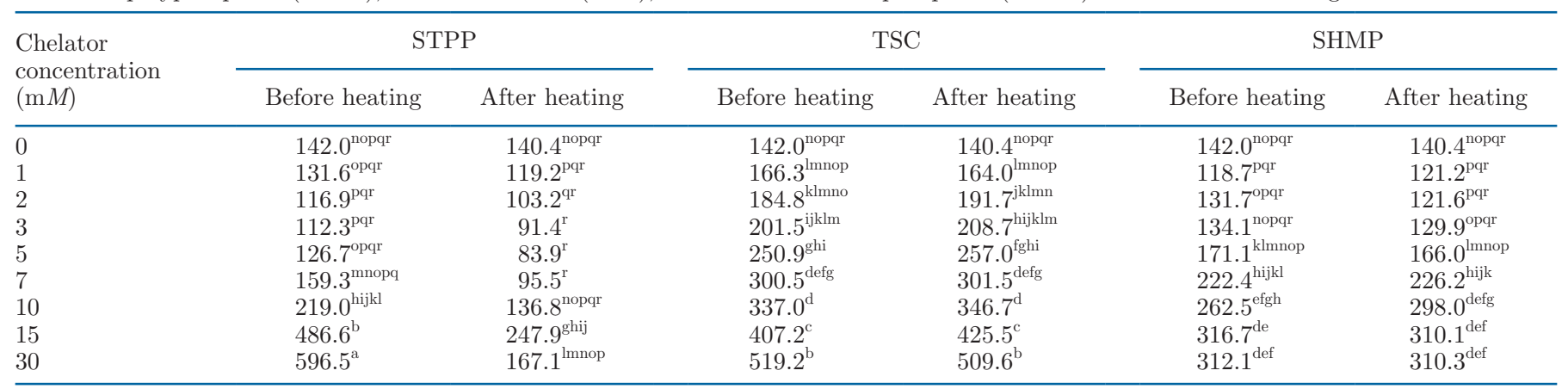

${ }^{\mathrm{a}-\mathrm{r}}$ Different superscript letters within the table indicate significant difference $(P<0.05)$.

${ }^{1}$ Numbers are mean values from duplicates.

and 2), which agrees with a previous study (Mizuno and Lucey, 2005). The amounts of casein-bound calcium and phosphorus may have decreased with the addition of TSC (Tables 1 and 2). The same may have been the case for STPP and SHMP treatments, except forming different types of calcium phosphate compounds that are different from those in TSC treatments, as suggested by different $\mathrm{Ca} / \mathrm{P}$ ratios. The lowest calcium concentration in SHMP treatments and the lower serum phosphorus concentration than the amount due to SHMP addition suggest that both minerals may have bound with proteins or formed insoluble complexes. The former is more likely because the turbidity was lower at a higher SHMP concentration (Figure 2). The speculation agrees with the reported binding of some calcium with proteins after addition of a small amount of SHMP in a previous study (Mizuno and Lucey, 2005).

For SMP treatments added with TSC, SHMP, and low concentrations of STPP, heating had no significant effect on the amount of solubilized calcium and phosphorus in the serum phase of SMP dispersions (Tables 1 and 2). When STPP concentration was $7 \mathrm{mM}$ and higher, the concentration of solubilized calcium decreased significantly after heating, whereas the significant decrease of solubilized phosphorus after heating was observed only at 15 and $30 \mathrm{mM}$ STPP. Based on decreased calcium and phosphorus concentrations (Tables 1 and 2) and both increased turbidity (Figure 2a) and $D_{\mathrm{h}}$ (Figure 3a) of SMP dispersions with 15 and $30 \mathrm{mM}$ STPP, it is likely that heating resulted in the reformation of the dissociated caseins as larger particles involving STPP but not TSC or SHMP (further examined using TEM below).

\section{Zeta-Potential of SMP Dispersions with Chelators}

The magnitude of negative zeta-potential of SMP dispersions at $\mathrm{pH} 6.80$ overall decreased $(P<0.05)$ with increasing concentrations of STPP, TSC, and SHMP (Table 3), but the changes were insignificant at

Table 2. Phosphorus concentration $(\mathrm{mg} / \mathrm{L}$ ) in the serum phase of $5 \%$ (wt/vol) $\mathrm{pH} 6.80$ skim milk powder dispersions after addition of 0 to 30 $\mathrm{m} M$ sodium tripolyphosphate (STPP), trisodium citrate (TSC), or sodium hexametaphosphate (SHMP) before or after heating at $90^{\circ} \mathrm{C}$ for 5 $\min ^{1}$

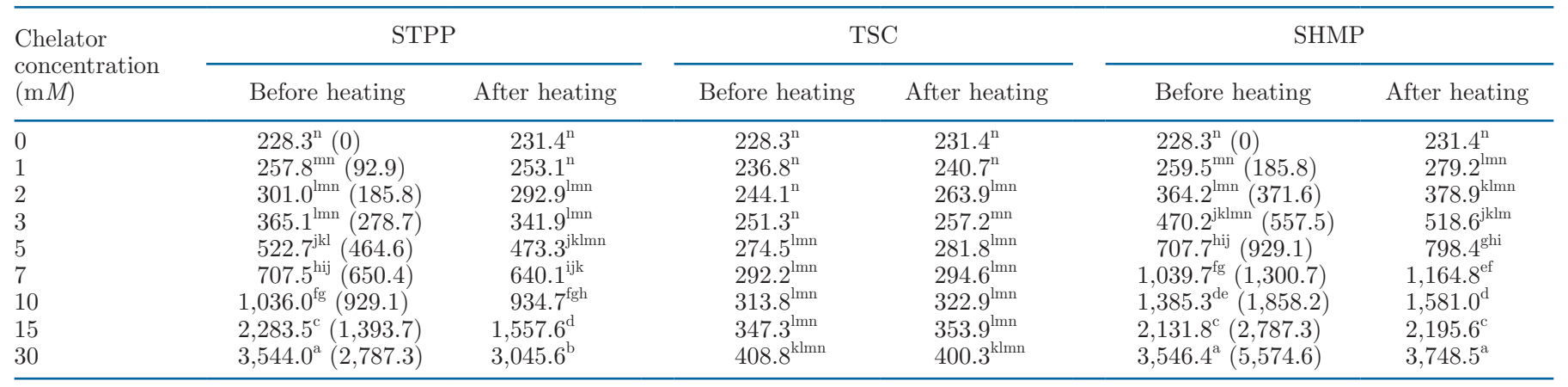

${ }^{\mathrm{a}-\mathrm{n}}$ Different superscript letters within the table indicate significant difference $(P<0.05)$.

${ }^{1}$ Numbers are mean values from duplicates. Numbers in parentheses are phosphorus concentrations $(\mathrm{mg} / \mathrm{L})$ calculated based on the amount of chelator added in the dispersion. 
Table 3. Zeta-potential of 5\% (wt/vol) skim milk powder dispersions after addition of 0 to $30 \mathrm{~m} M$ sodium tripolyphosphate (STPP), trisodium citrate (TSC), or sodium hexametaphosphate (SHMP) and adjusting $\mathrm{pH}$ to 6.80

\begin{tabular}{|c|c|c|c|c|c|c|}
\hline \multirow{2}{*}{$\begin{array}{l}\text { Chelator } \\
\text { concentration } \\
(\mathrm{m} M)\end{array}$} & \multicolumn{3}{|c|}{$\begin{array}{l}\text { Theoretical ionic strength with complete } \\
\text { dissociation of chelator }(\mathrm{m} M)\end{array}$} & \multicolumn{3}{|c|}{ Zeta-potential $^{1}(\mathrm{mV})$} \\
\hline & STPP & $\mathrm{TSC}$ & SHMP & STPP & TSC & SHMP \\
\hline 1 & 15 & 6 & 21 & $-14.07 \pm 1.58^{\text {cde }}$ & $-12.90 \pm 1.65^{\mathrm{e}}$ & $-15.00 \pm 1.16^{\text {abcd }}$ \\
\hline 2 & 30 & 12 & 42 & $-15.00 \pm 0.77^{\mathrm{abcd}}$ & $-14.17 \pm 1.01^{\mathrm{bcde}}$ & $-15.25 \pm 1.35^{\mathrm{abc}}$ \\
\hline 3 & 45 & 18 & 63 & $-15.88 \pm 1.45^{\mathrm{a}}$ & $-14.08 \pm 1.13^{\text {cde }}$ & $-15.43 \pm 1.16^{\mathrm{ab}}$ \\
\hline 10 & 150 & 60 & 210 & $-11.22 \pm 0.59^{\mathrm{f}}$ & $-14.78 \pm 0.95^{\mathrm{abcd}}$ & $-10.54 \pm 0.72^{\mathrm{fgh}}$ \\
\hline 15 & 225 & 90 & 315 & $-9.31 \pm 1.57^{\mathrm{h}}$ & $-10.83 \pm 0.78^{\mathrm{fg}}$ & $-10.48 \pm 0.59^{\mathrm{fgh}}$ \\
\hline 30 & 450 & 180 & 630 & $-9.80 \pm 1.15^{\mathrm{gh}}$ & $-10.20 \pm 0.74^{\mathrm{fgh}}$ & $-9.57 \pm 0.76^{\mathrm{gh}}$ \\
\hline
\end{tabular}

$\overline{\mathrm{a}-\mathrm{h}}$ Different superscript letters within the table indicate significant difference $(P<0.05)$.

${ }^{1}$ Numbers are mean $\pm \mathrm{SD}(\mathrm{n}=2)$.

low chelator concentrations. At an increased chelator concentration, calcium and phosphorus concentrations in the serum of SMP dispersions increased (Tables 1 and 2). The increased ionic strength lowers electrophoretic mobility and therefore the measured zeta-potential magnitude (Ricq et al., 1998). When different chelators are compared, the contribution of calcium chelators to the ionic strength follows the decreasing order of SHMP $>$ STPP $>$ TSC (Table 3). However, the zeta-potential magnitude was similar $(P>0.05)$ at the same chelator concentration. The zeta-potential data suggest a portion of chelator ions bound with caseins, which agrees with the measured serum $\mathrm{Ca}$ and $\mathrm{P}$ concentrations in Tables 1 and 2. Additionally, the interpretation of zetapotential results is further complicated by the dynamic equilibria between various forms of calcium phosphates (Kezia et al., 2017), which determines the $\mathrm{Ca} / \mathrm{P}$ ratio in the serum to affect the ionic strength and therefore the measured zeta-potential. At this point, understanding the specific forms of calcium phosphates is still needed. In addition, not all calcium and phosphorus released from casein micelles is soluble after addition of chelators; this complicates the actual ionic strength in SMP dispersions and therefore interpretation of the measured zeta-potential.

\section{Structural Changes of Calcium-Chelated Casein Micelles Studied Using TEM}

Casein micelles in SMP dispersions without addition of calcium chelators were mostly spherical (Figure 5a) and had a diameter of around 150 to $200 \mathrm{~nm}$. Some aggregated particles larger than $400 \mathrm{~nm}$ (Figure 5a3) were also observed, which can be contributed to by the incomplete hydration of SMP and resulted in the mean $D_{\mathrm{h}}$ of $\sim 280 \mathrm{~nm}$ (Figure 3 ). After heating, such aggregated structures were not observed (Figures 5a4, a-5, and a-6). As casein micelles in milk are stable after thermal sterilization (Singh, 2004; Tsioulpas et al., 2010), TEM images suggest the enhanced hydration of SMP powder after heating, which agrees with the reduced $D_{\mathrm{h}}$ after heating (Figure 3 ).

The TEM images of SMP dispersions with STPP, TSC, or SHMP at the concentrations of 1, 7, and 30 $\mathrm{m} M$ before and after heating are shown in Figure 5b, $5 \mathrm{c}$, and $5 \mathrm{~d}$, respectively. At $1 \mathrm{~m} M$ chelator, SMP dispersions with STPP and TSC had a morphology (Figure 5b-1 and c-1) comparable with that of casein micelles without chelators (Figure 5a). In contrast, $1 \mathrm{~m} M$ SHMP resulted in structures much smaller than intact casein micelles, some appearing as aggregates of dissociated caseins (Figure 5d-1). The TEM images support the smaller $D_{\mathrm{h}}$ (Figure 3 ) and turbidity (Figure 2) of SMP dispersion with $1 \mathrm{~m} M$ SHMP than those with the same concentration of STPP or TSC. As chelator concentration increased from 1 to $7 \mathrm{~m} M$, smaller structures were observed (Figure 5b-2, c-2, and d-2), indicating further dissociation of casein micelles and agreeing with the reduction in $D_{\mathrm{h}}$ (Figure 3 ) and dispersion turbidity (Figure 2). When the chelator concentration was further increased to $30 \mathrm{~m} M$, darker images with higher density were observed for STPP (Figure 5b-3) and TSC (Figure 5c-3) treatments, indicating the aggregated caseins, whereas the SHMP treatment showed highly aggregated structures (Figure 5d-3). Sodium hexametaphosphate has 6 negative charges distributed evenly around the molecule and therefore the ability to crosslink caseins (de Kort et al., 2011), resulting in the aggregated structures at $30 \mathrm{~m} M$ SHMP (Figure 5d-3). The aggregated caseins may be responsible for the larger $D_{\mathrm{h}}$ of dispersions with $30 \mathrm{~m} M$ chelators than $7 \mathrm{~m} M$ chelators, particularly for the SHMP treatment (Figure 

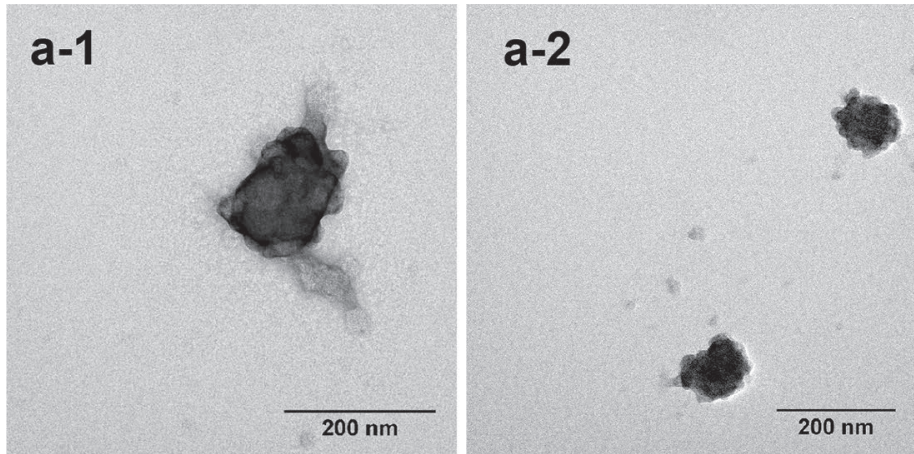

\section{a-3}
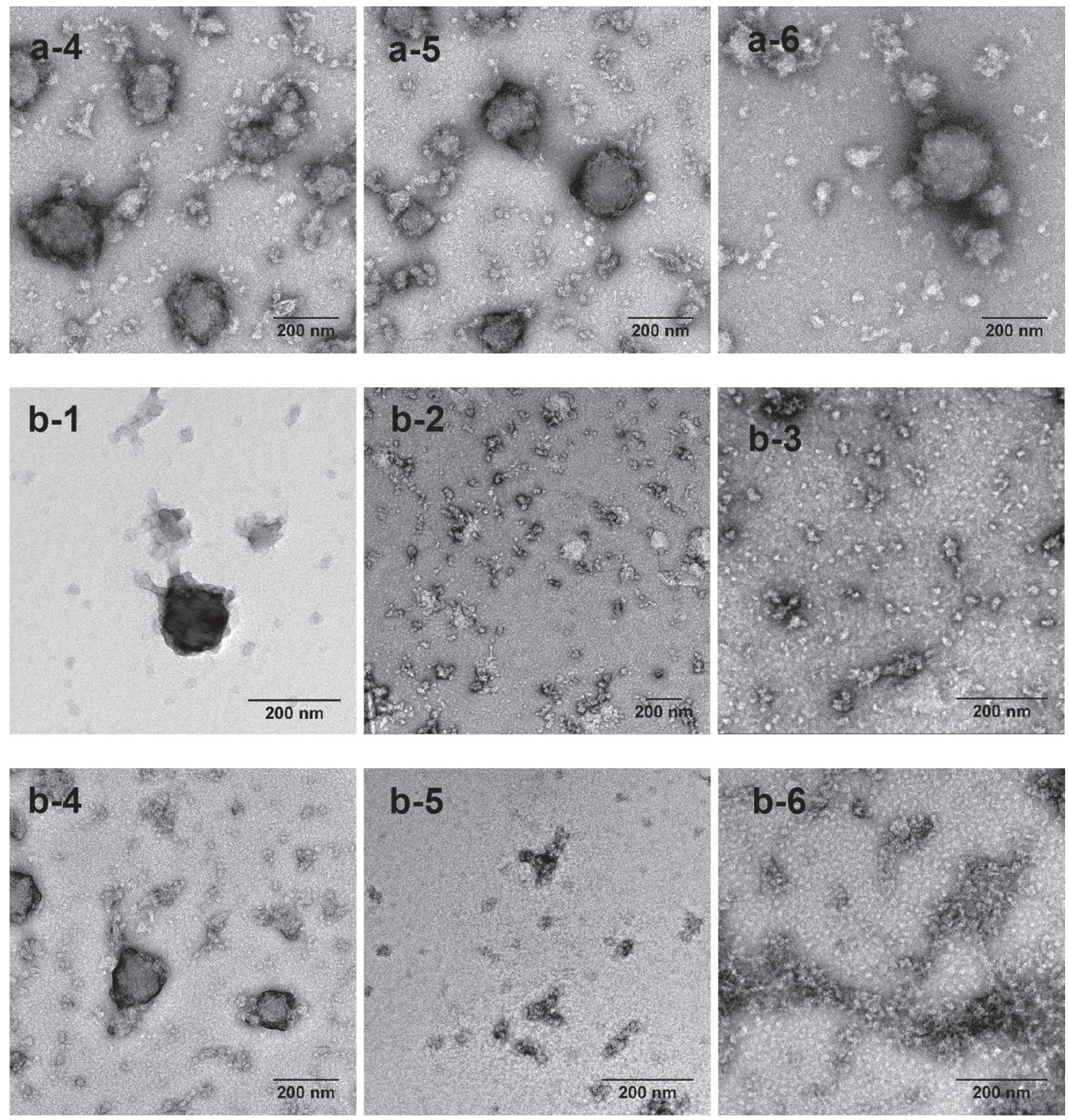

Figure 5. Transmission electron microscopy images of 5\% (wt/vol) skim milk powder dispersion at $\mathrm{pH} 6.80$ without chelator (a) or with 1 $\mathrm{m} M$ (1 and 4), $7 \mathrm{mM}(2$ and 5), or $30 \mathrm{~m} M$ (3 and 6) sodium tripolyphosphate (b), trisodium citrate (c), or sodium hexametaphosphate (d) before (1-3) and after (4-6) heating at $90^{\circ} \mathrm{C}$ for 5 min. Dispersions were diluted to $1 \%$ (wt/vol) skim milk powder with the serum before imaging. 

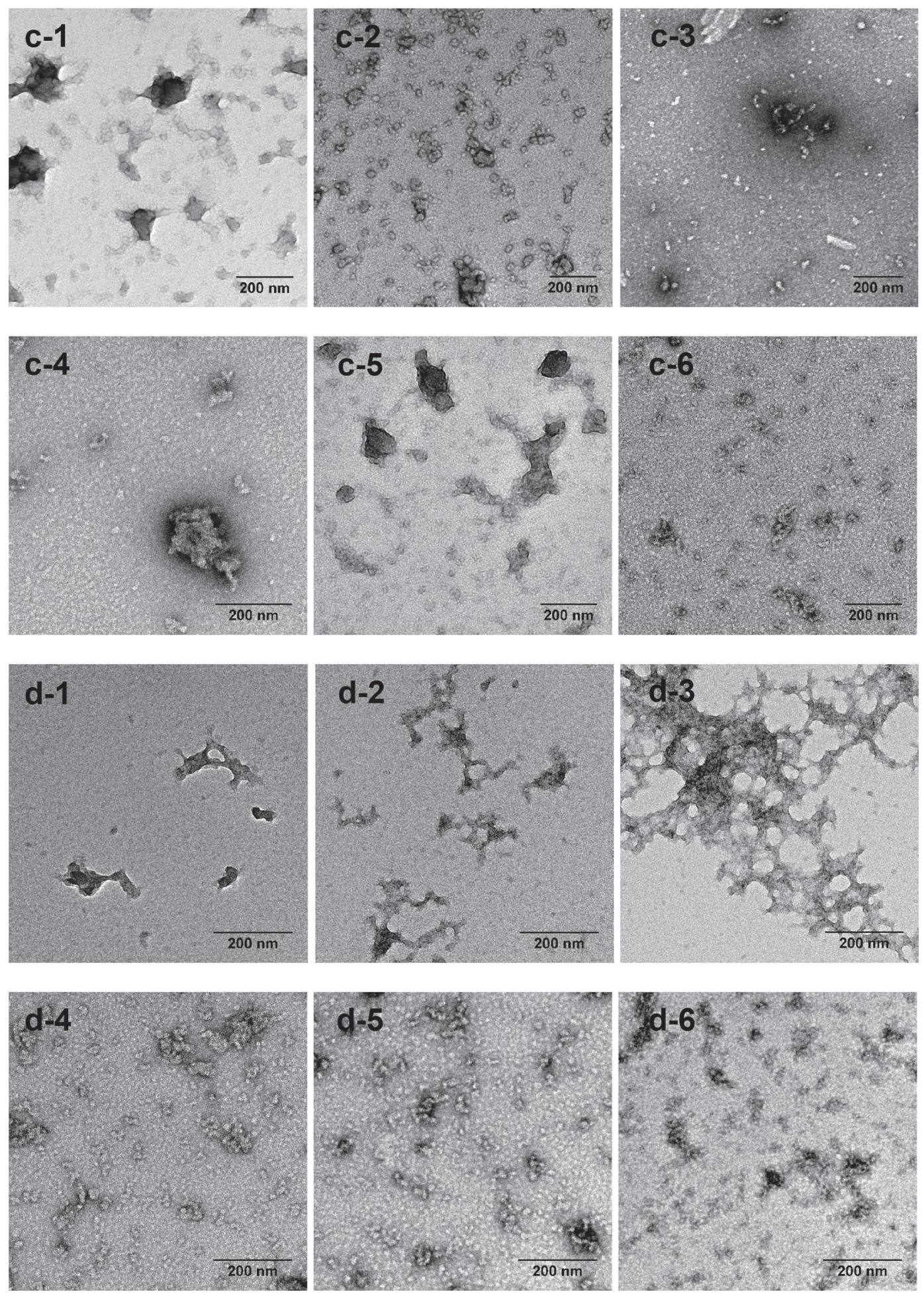

Figure 5 (Continued). Transmission electron microscopy images of $5 \%$ (wt/vol) skim milk powder dispersion at pH 6.80 without chelator (a) or with $1 \mathrm{~m} M$ (1 and 4), $7 \mathrm{mM}$ (2 and 5), or $30 \mathrm{~m} M(3$ and 6$)$ sodium tripolyphosphate (b), trisodium citrate (c), or sodium hexametaphosphate (d) before (1-3) and after (4-6) heating at $90^{\circ} \mathrm{C}$ for $5 \mathrm{~min}$. Dispersions were diluted to $1 \%$ (wt/vol) skim milk powder with the serum before imaging. 
3). The reduced ability of dissociated caseins, with a less dense structure, compared with casein micelles to scatter light corresponded to the further decrease in turbidity at $30 \mathrm{~m} M$ chelator (Figure 2), even for highly aggregated structures of the SHMP treatment.

In general, heating caused a greater extent of casein micelle dissociation for dispersions with chelators (Figure 5), agreeing with the decreased $D_{\mathrm{h}}$ after heating (Figure 3). The exceptions in increased $D_{\mathrm{h}}$ and turbidity after heating the SMP dispersion with $30 \mathrm{~m} M \mathrm{STPP}$ and $7 \mathrm{mM}$ TSC were supported by formation of slightly larger aggregated particles (Figure 5b-6 and c-5). Morphological changes after heating SMP dispersions with different amounts and types of chelators again suggest the complex dynamics of calcium phosphate compounds in the serum and their binding with caseins, as discussed previously. In the future, detailed analyses of different forms of calcium phosphate compounds in the serum and their binding with caseins will be needed to clearly establish correlations between macroscopic turbidity and mesoscopic structures probed in light scatting and TEM.

\section{CONCLUSIONS}

The turbidity of 5\% (wt/vol) SMP dispersions was effectively lowered using STPP, TSC, and SHMP. A higher chelator concentration resulted in a less turbid dispersion due to a greater extent of chelating calcium from CCP to result in dissociation of casein micelles. Trisodium citrate was the most effective in releasing calcium from casein micelles, whereas SHMP decreased the turbidity of the dispersions the most, suggesting differences in the mechanism of calcium chelation and the possible complex formation between calcium and chelators. The $D_{\mathrm{h}}$ of SMP dispersions started to decrease with the initial increase of the chelator concentration, mostly contributed by the chelating effect. However, at higher concentrations of chelators, chelators caused the aggregation of dissociated casein micelles, as observed in dynamic light scattering and TEM. In particular, heating greatly increased the turbidity and $D_{\mathrm{h}}$ of SMP dispersions with 15 and $30 \mathrm{mM}$ STPP but decreased $D_{\mathrm{h}}$ of the dispersion with SHMP. Differences in macroscopic turbidity of SMP dispersions and mesoscopic structures point to the need to study specific forms of calcium phosphates in the serum phase and their binding with proteins as affected by chelator type and concentration. Nevertheless, findings in this study may be used to formulate shelf-stable and heat-stable beverages with improved clarity containing significant contents of casein micelles.

\section{ACKNOWLEDGMENTS}

The authors extend their appreciation to John Dunlap, Michael Essington, and Melanie Stewart (University of Knoxville, Tennessee), who provided assistance for the experiments. This study was supported by USDA National Institute of Food and Agriculture (Washington, DC), TEN2015-05921, and hatch projects TEN00487 and 223984. Any opinions, findings, conclusions, or recommendations expressed in this publication are those of the authors and do not necessarily reflect the view of the USDA. The authors have not stated any conflicts of interest.

\section{REFERENCES}

AOAC International. 2005. AOAC Official Method 930.29: Protein in dried milk. AOAC Int., Gaithersburg, MD.

Bravo, F. I., X. Felipe, R. López-Fandiño, and E. Molina. 2013. Highpressure treatment of milk in industrial and pilot-scale equipments: Effect of the treatment conditions on the protein distribution in different milk fractions. Eur. Food Res. Technol. 236:499-506. https://doi.org/10.1007/s00217-012-1902-9.

Culler, M. D., Y. Saricay, and F. M. Harte. 2017. The effect of emulsifying salts on the turbidity of a diluted milk system with varying pH and protein concentration. J. Dairy Sci. 100:4241-4252. https: //doi.org/10.3168/jds.2017-12549.

Dalgleish, D. G., and M. Corredig. 2012. The structure of the casein micelle of milk and its changes during processing. Annu. Rev. Food Sci. Technol. 3:449-467. https://doi.org/10.1146/annurev-food -022811-101214.

de Kort, E., M. Minor, T. Snoeren, T. Van Hooijdonk, and E. Van Der Linden. 2009. Calcium-binding capacity of organic and inorganic ortho-and polyphosphates. Dairy Sci. Technol. 89:283-299. https:/ /doi.org/10.1051/dst/2009008.

de Kort, E., M. Minor, T. Snoeren, T. van Hooijdonk, and E. van der Linden. 2011. Effect of calcium chelators on physical changes in casein micelles in concentrated micellar casein solutions. Int. Dairy J. 21:907-913. https://doi.org/10.1016/j.idairyj.2011.06.007.

de Kort, E., M. Minor, T. Snoeren, T. van Hooijdonk, and E. van der Linden. 2012. Effect of calcium chelators on heat coagulation and heat-induced changes of concentrated micellar casein solutions: The role of calcium-ion activity and micellar integrity. Int. Dairy J. 26:112-119. https://doi.org/10.1016/j.idairyj.2012.03.014.

DeMan, J. M., J. W. Finley, W. J. Hurst, and C. Y. Lee. 1999. Principles of Food Chemistry. Springer, Berlin, Germany.

Dorozhkin, S. 2014. Calcium orthophosphates: Occurrence, properties and major applications. Bioceram. Dev. Appl. 4:2. https://doi .org/10.4172/2090-5025.1000081.

Gaucheron, F. 2005. The minerals of milk. Reprod. Nutr. Dev. 45:473483. https://doi.org/10.1051/rnd:2005030.

Glantz, M., T. Devold, G. Vegarud, H. Lindmark Månsson, H. Stålhammar, and M. Paulsson. 2010. Importance of casein micelle size and milk composition for milk gelation. J. Dairy Sci. 93:14441451. https://doi.org/10.3168/jds.2009-2856.

Henchion, M., M. Hayes, A. Mullen, M. Fenelon, and B. Tiwari. 2017. Future protein supply and demand: Strategies and factors influencing a sustainable equilibrium. Foods 6:53. https://doi.org/10 $.3390 /$ foods 6070053 .

Horne, D. S. 1998. Casein interactions: Casting light on the black boxes, the structure in dairy products. Int. Dairy J. 8:171-177. https://doi.org/10.1016/S0958-6946(98)00040-5.

Horne, D. S. 2006. Casein micelle structure: Models and muddles. Curr. Opin. Colloid Interface Sci. 11:148-153. https://doi.org/10 .1016/j.cocis.2005.11.004. 
Huppertz, T., and C. G. De Kruif. 2007. Disruption and reassociation of casein micelles during high pressure treatment: Influence of whey proteins. J. Dairy Res. 74:194-197. https://doi.org/10.1017/ S0022029906002263.

Jonassen, H., A.-L. Kjøniksen, and M. Hiorth. 2012. Effects of ionic strength on the size and compactness of chitosan nanoparticles. Colloid Polym. Sci. 290:919-929. https://doi.org/10.1007/s00396 -012-2604-3.

Kaliappan, S., and J. A. Lucey. 2011. Influence of mixtures of calcium-chelating salts on the physicochemical properties of casein micelles. J. Dairy Sci. 94:4255-4263. https://doi.org/10.3168/jds .2010-3343.

Kezia, K., J. Lee, B. Zisu, G. Chen, S. Gras, and S. Kentish. 2017. Solubility of calcium phosphate in concentrated dairy effluent brines. J. Agric. Food Chem. 65:4027-4034. https://doi.org/10.1021/acs .jafc.6b05792.

LaClair, C. E., and M. R. Etzel. 2010. Ingredients and pH are key to clear beverages that contain whey protein. J. Food Sci. 75:C21C27. https://doi.org/10.1111/j.1750-3841.2009.01400.x.

Lazzaro, F., A. Saint-Jalmes, F. Violleau, C. Lopez, M. Gaucher-Delmas, M.-N. Madec, E. Beaucher, and F. Gaucheron. 2017. Gradual disaggregation of the casein micelle improves its emulsifying capacity and decreases the stability of dairy emulsions. Food Hydrocoll. 63:189-200. https://doi.org/10.1016/j.foodhyd.2016.08.037.

Lucey, J., and P. Fox. 1993. Importance of calcium and phosphate in cheese manufacture: A review. J. Dairy Sci. 76:1714-1724. https:/ /doi.org/10.3168/jds.S0022-0302(93)77504-9.

Lucey, J. A., A. Maurer-Rothmann, and S. Kaliappan. 2011. Functionality of ingredients: Emulsifying salts. Pages 110-132 in Processed Cheese and Analogues. A. Y. Tamime, ed. Wiley-Blackwell, Hoboken, NJ.

MacKenzie-Shalders, K. L., N. M. Byrne, G. J. Slater, and N. A. King. 2015. The effect of a whey protein supplement dose on satiety and food intake in resistance training athletes. Appetite 92:178-184. https://doi.org/10.1016/j.appet.2015.05.007.

McCarthy, N. A., O. Power, H. B. Wijayanti, P. M. Kelly, L. Mao, and M. A. Fenelon. 2017. Effects of calcium chelating agents on the solubility of milk protein concentrate. Int. J. Dairy Technol. 70:415-423. https://doi.org/10.1111/1471-0307.12408.

McIntyre, I., M. O'Sullivan, and D. O'Riordan. 2016. Effects of calcium chelators on calcium distribution and protein solubility in rennet casein dispersions. Food Chem. 197:233-239. https://doi .org/10.1016/j.foodchem.2015.10.084.

Mizuno, R., and J. Lucey. 2005. Effects of emulsifying salts on the turbidity and calcium-phosphate-protein interactions in casein micelles. J. Dairy Sci. 88:3070-3078. https://doi.org/10.3168/jds .S0022-0302(05)72988-X.

Orlien, V., L. Boserup, and K. Olsen. 2010. Casein micelle dissociation in skim milk during high-pressure treatment: Effects of pressure,
pH, and temperature. J. Dairy Sci. 93:12-18. https://doi.org/10 $.3168 /$ jds.2009-2244.

Panouillé, M., L. Benyahia, D. Durand, and T. Nicolai. 2005. Dynamic mechanical properties of suspensions of micellar casein particles. J. Colloid Interface Sci. 287:468-475. https://doi.org/10.1016/j.jcis .2005.02.007.

Pitkowski, A., T. Nicolai, and D. Durand. 2008. Scattering and turbidity study of the dissociation of casein by calcium chelation. Biomacromolecules 9:369-375. https://doi.org/10.1021/bm7006899.

Ricq, L., A. Pierre, J.-C. Reggiani, J. Pagetti, and A. Foissy. 1998. Use of electrophoretic mobility and streaming potential measurements to characterize electrokinetic properties of ultrafiltration and microfiltration membranes. Colloids Surf. A Physicochem. Eng. Asp. 138:301-308. https://doi.org/10.1016/S0927-7757(97)00071-X.

Rittmanic, S. 2006. US Whey Proteins in Ready-to-Drink Beverages. US Dairy Export Council, Arlington, VA.

Saricay, Y., C. A. Hettiarachchi, M. D. Culler, and F. M. Harte. 2019. Critical phosphate salt concentrations leading to altered micellar casein structures and functional intermediates. J. Dairy Sci. 102:6820-6829. https://doi.org/10.3168/jds.2018-15746.

Schmidt, D. G. 1982. Association of caseins and casein micelle structure. Pages $61-86$ in Developments in Dairy Chemistry. P. F. Fox, ed. Elsevier, London, UK.

Seow, W. K, and K. Thong. 2005. Erosive effects of common beverages on extracted premolar teeth. Aust. Dent. J. 50:173-178. https:// doi.org/10.1111/j.1834-7819.2005.tb00357.x.

Singh, H. 2004. Heat stability of milk. Int. J. Dairy Technol. 57:111119. https://doi.org/10.1111/j.1471-0307.2004.00143.x.

Tsioulpas, A., A. Koliandris, A. Grandison, and M. Lewis. 2010. Effects of stabiliser addition and in-container sterilisation on selected properties of milk related to casein micelle stability. Food Chem. 122:1027-1034. https://doi.org/10.1016/j.foodchem.2010.03.063.

United Nations. 2015. The World Population Prospects: 2015 Revision. Accessed Feb. 10, 2020. https://www.un.org/en/development/ desa/publications/world-population-prospects-2015-revision.html.

Van Wazer, J. R., and C. F. Callis. 1958. Metal complexing by phosphates. Chem. Rev. 58:1011-1046. https://doi.org/10.1021/ cr50024a001.

Walstra, P. 1999. Dairy Technology: Principles of Milk Properties and Processes. CRC Press, Boca Raton, FL.

\section{ORCIDS}

Inseob Choi (1) https://orcid.org/0000-0002-6375-4059

Qixin Zhong (1) https://orcid.org/0000-0002-6071-342X 